\title{
The Impact of Employee Empowerment on Intellectual Capital and Organizational Citizenship Behavior: Moderating role of Demographic
} \author{
Jwmaa d and Farman Badran Jalal e \\ A \\ Department of Business Administration, Administration Technical College, Erbil \\ Polytechnic University and Universiti Tun Hussein Onn, Malaysia. \\ Specialization: Accunting and Finance. \\ ${ }^{\mathbf{b}}$ Faculty Technology Management and Business, Universiti Tun Hussien Onn \\ Malaysia 86400 Parit Raja, Johor, Malaysia \\ CHead of tourism administration department at Lebanese French University \\ D Department of Accounting, College of Administrative \& Financial \\ Sciences, Knowledge University, Iraq. \\ E Bayan University - Erbil, Kurdistan Region. Iraq.
}

Nawzad Majeed Hamawandy ${ }^{\mathrm{a}}$, Abdul Jalil Omer ${ }^{\mathrm{b}}$, Houshyar Abdulrahman Salih ${ }^{\mathrm{c}}$, Soran Jawamir

Article History: Received: 11 January 2021; Accepted: 27 February 2021; Published online: 5 April 2021

\begin{abstract}
In recently, human resources management measured as the most worth able resource has been the center of approaches, activities and it plays an important role in promoting the objectives and goals of the organization. In fact the financial paradigms do not meet the requirements and expectations of the organization, it has led organizations to seek other paths to achieve competitive advantages. In this study, the growth of intellectual capital and organizational citizenship behavior can be taking new approaches in to account field. Practices for development going beyond the role of recognized expectations needs vital infrastructures. Therefore, empowerment is an important element to plays positive role to describing about social exchange of organizational citizenship behavior. Alternatively, in the economy of knowledge-based, the intellectual capital is the creating knowledge and sharing to enhance enterprise values. The study based on descriptive analysis and it examine the relationship between employee's empowerment, intellectual capital and organizational citizenship behavior. To the theoretical data collection and to extract initial factors and indicators, library and Internet resources were used and questionnaire was used to gather the data needed to evaluate the assumptions. In this research, random method sampling has been used and Pearson's correlation coefficient was used to analysis data. The findings of study state that a positive and significant relationship occurs between dimensions of employee's empowerment with growth of Intellectual capital and organizational citizenship behavior. On the other hand, becoming more empowered, employees` growth of intellectual capital has increased and the organization will enjoy more progressive staff.
\end{abstract}

Keywords: Empowerment, Intellectual capital, Organizational citizenship behavior, Demographics.

\section{Introduction}

Nowadays, human resources known as one of the most valuable organizational asset is considered as the competitive advantage and the most scarce source in knowledge -based economy .To create innovative ideas and original insights and to respond to events occurring in the workplaces effectively, employees- as the important intangible asset- can be used (Chang,2008). In today's varying environment, organizations facing with the complex and turbulent environment have no alternative except appropriate utilization of human resources. Accordingly, empowerment will be the only factor to achieve balance in employees`empowerment organization. In addition, organizational citizenship behavior and growth of intellectual capital have also shown their effects on organizational success and achieving higher productivity of human resources. Organizational Citizenship Behavior improves roles and duties in organization with a set of voluntary behaviors and development of intellectual capital directs organizations and societies to the growth and development. Accordingly, studying and identifying the relationship between these two effective factors on qualitative and quantitative improvement of behaviors and thus improving the performance of human resources were the main goals of this research (Appelbaum \& Bartolomucci, 2004; May \& Harter, 2004).

\section{Concepts and Theoretical Approaches}

\subsection{Empowerment}

The history of the first definition of "empowerment" term dates back to 1788 , in which the empowerment was known as delegation of authority in individual's organizational role. This authority needs to be granted to an individual or seen in his organizational role (Aghayar, 2003). The existence of corporate governance systems aims to achieve economic efficiency, with a strong emphasis on increasing shareholders' wealth (Al-Kake \& Hasan, 2019). Its relationship with economic growth have generated excessive interest among economic researchers over time (Baban \& Hasan, 2019). In other words, empowerment is the collection of systems, procedures and measures taken in to account in order to improve and increase productivity, growth, and prosperity of the organization and 
human resources through development and capabilities of individuals. Thomas and Vltvs (1990) provided a comprehensive definition for empowerment and they added psychological term to this definition. According to them, psychological empowerment is considered as a set of cognitive-motive domains in which it includes other cognitive domains in addition to its self-efficiency (Methane, 2009). The idea of capital competence is a newly developed concept that is being explored in research (Gardi et al., 2020). KM is therefore considered as a critical aspect of an organization given the fact that its proponents radically complement the business functions and activities of an entity (Jabbar et al., 2019). Turkish economy was basically an agricultural economy till it moved to the modern and commerce economy (Hasan et al., 2019).This theory assumes that there is a relationship between the principal owners and the agent or steward who agrees to undertake assigned tasks (shezad, hamawandy, 2020). it shows that the growth on countless developmental issues was not satisfactory in emerging countries (Ogiemwonyi et al., 2020). One of the major motive behind changes in internal control is surrounded with vast activities of gross corporate misconducts (Mahmood et al., 2020). The most important factors in the economic growth processing of any country are the commercial transactions and foreign direct investments (FDI) (Adl.Nawzad, 2020). The theory of constraints is based on the assertion that firms thrive to make profits both presently and in the foreseeable future (Omar \& Hasan, 2020). Quality of auditing means the extent of adherence to auditing standards, and individual performance standards within the audit facility.(Karim et al., 2020). Turkish economy during the late 1970's as a result of the problem in balance of payment forced the government to adopt a new industrialization strategy which made it able to alleviate this problem((Hamawandy et al., 2020). The disclosure of the sustainable development dimensions aims to make financial reports more reliable, transparence and comparable, which improves the quality of financial reports(Abdullah et al., 2021).

\section{General approaches to empowerment}

A. The structural approach: According to this approach, empowerment is delegation of authority and power to inferiors. This means that the authority is delegated to non-managers in terms of making important organizational decisions. The following diagram shows process of structural empowerment:

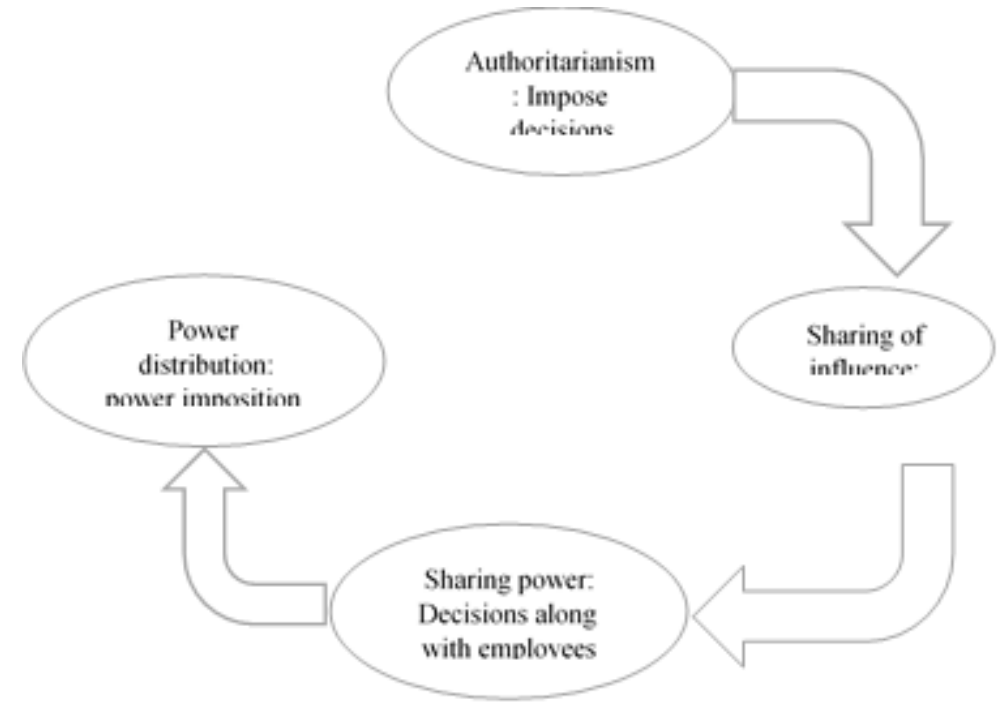

Empowerment process diagram

B. The psychological approach: This approach is broadly defined as state of internal motivation in relation to job and it indicates individuals` willingness to their roles.

\section{According to Mishra, empowerment enjoys the following dimensions:}

Empowerment means creating a sense of competence, feeling of having the right of selection, feeling of being effective, and sense of being meaningful for the job and finally the sense of trusting in others (Mishra,1992). Sense of being effective: the person`s belief to the fact that how much his performance will be effective to accomplish the objectives.

Sense of competence: is one's belief in his own capabilities to perform a task. Sense of being meaningful: this assessment pays attention to the fact that how an individual look toward to the goal considering his desires and standards. Self-determination: is accountability for results where the person is responsible for creating them.

Trust: is related to interest and confidence in others (Thomas \& Velthouse, 1990).

\subsection{1. $\quad$ Factors Affecting Staff Empowerment}

Effective factors on staff empowerment in organization can be summarized as following:

- Clear objectives, responsibilities and authorities in organization. Job enrichment and job promotion of staff. 
- Participation, teamwork and trust atmosphere, sincerity and honesty. Work environment and communication.

- Information, knowledge, and job skills. Optimization process and work methods.

\subsubsection{The Movement of Organizational Development and Employees` Empowerment}

Concepts of behavioral science provide the necessary areas for organization`s improvement or development movement meaning that they provide purposeful and planned changes to increase the effectiveness of the organization's structure, processes, technology or individuals.

The summary of improvement philosophy of organization from Warren Bennis's point of view includes the following definitions:

- A new concept of human according to increasing complex knowledge and changing needs instead of a simple human being with inflexible beliefs.

- New concept of power is according to reasoning and cooperation rather than threats and repression.

- A new concept of organization values is based on humanistic concepts rather than bureaucratic and instrumental values.

In fact, the organizational development movement came up with the idea of implementing designed programs to improve the effectiveness according to improvement of tasks within an organization and responding the changes with special focus on the fact that how individuals do their duties and how they interact with each other.

\subsection{The Organizational Citizenship Behavior}

The concept of organizational citizenship behavior was first introduced by Batman and Organ in the early 1980s. Initial research conducted on organizational citizenship behavior were more for recognizing responsibilities and/or behaviors which employee had in organization but always were neglected. Although these behaviors were measured incompletely in traditional assessments of job performance and even sometimes were neglected, were effective in improving effectiveness (Batman and organ, 1983). These practices which occur in work environment are defined as follow "a set of volunteer and optional behaviors which are not part of official duties of people, but are done and improve duties and roles of organization. Organ states that organizational citizenship behavior is a personal and volunteer behavior which is not directly influenced by official reward system in organizations, but promotes effectiveness and efficiency organization's performance (Mishra, 1992). This definition emphasizes on three main characteristics of citizenship behavior: first, this behavior id volunteer and optional and not a predetermined duty or part of official duties of person. Second, the benefits of this behavior are organizational that is this behavior diffuses the effective performance of organization. And the third characteristic is that it is not valued directly ln official reward system.

Based on Organ's theory, the aspects of organizational citizenship behavior are:

i. Altruism: altruism is related to volunteer help to certain people in work environment and in relation to an organizational duty or problem.

ii. Loyalty: includes behavior which allow person to conduct him/her duties higher than the expected level.

iii. Chivalry: the tendency of person to bear non ideal conditions without any complaint for real deficiencies. Chivalry is related to work group performance such that managers spend less energy and time for coordinating members and can spend most of their time for planning, designing, problem solving, and organizational analysis activities.

iv. Politeness and Kindness: includes behaviors that prevent from occurrence of problems, like avoiding occurrence of problems for colleagues and/or consultation before action.

v. Civil virtue: is a behavior that shows a person is sensitive to organization's life and engage responsibly. Civil virtue includes constructive suggestions about how work group can promote its efficiency. This nature-based issue releases resources or increases employee efficiency and improves group's performance by active and attentive involvement.

\subsection{Anti -Citizenship Behavior}

Anti-citizenship behaviors are the bad behavior of employees which reduces the employees' output. Dimensions of anti-citizenship behavior include being stubborn and carefree, resisting against authority, dodging, hatred, and aggression. Social friction and organizational mismatch of effective factors on anti-citizenship behavior several factors such as injustice, competition within the organization, and job stress can lead to the anti-citizen behavior. However, according to conducted research, existence of social friction (negative feelings and emotions such as anger and reluctance directed towards the certain target or person) and organizational mismatch (heterogeneity of personal values of employees with the culture, and strategic needs, organization`s norms and values) can create considerable effects on occurrence of anti-citizenship behavior (Seyed Javadin, 2013).

\subsection{Intellectual Capital}

A review of the literature shows that the organizations have three types of capitals including financial, physical, and intellectual. In the knowledge-based economy, the success of an organization depends on the management of 
intellectual capital. Nowadays, the intellectual capital is among the most important assets of organizations because the success and achievement of sustainable competitive advantage in the organization roots in their intellectual capabilities. According to most definitions by researchers, it can be concluded that the intellectual capital is nonmonetary asset without physical presence but it is valuable and producing the advantages and benefits in the future. Intellectual capital is the effort for effective usage of knowledge (final product) compared to information (raw material). Intellectual capital is a term used for mixing intangible assets of market, intellectual asset, human asset, and infrastructural asset which is enabling the organization to do their activities. (Brooking, 1996). In other words, intellectual capital is an important intellectual factor including knowledge, information, intellectual property, and experience which can be helpful for creation of wealth. This collection contains intellectual power or beneficial knowledge. (Stewart, 1997).

\subsubsection{Dimensions of Intellectual Capital}

\section{- Human capital}

It is a collection of implicit and explicit knowledge of employees which is considered valuable for the organization. In other words, human capital is defined as a combination of knowledge, skills, initiative and ability to perform the duties of employees. It also includes the values, culture, and organizational environment.

- The structural capital

It is the implicit knowledge related to internal processes of the organization in terms of distribution, communication, and scientific and technical knowledge management. This capital includes hardware, software, data bases, organizational structure, patents, trademarks and other organizational capabilities in order to support productivity.

- The social capital

This includes the knowledge placed and used in interaction among individuals and networks of their mutual relations. Social capital reveals the importance of a strong network of relationships based on trust and cooperation in communities. (Seyed Javadin, 2014).

Research analytical model (Spreitzer, 2007)

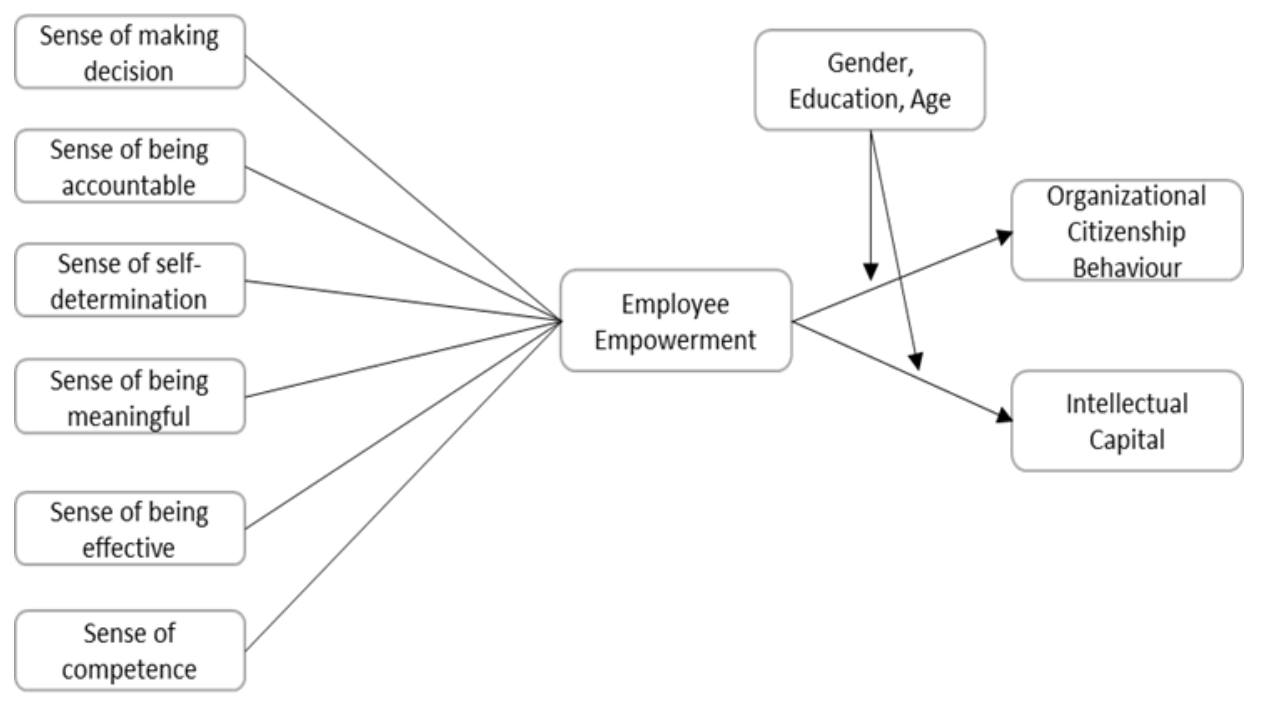

According to the model: Psychological empowerment through Spritzer models as independent variable; organizational citizenship behavior through Organ model; intellectual capital of Benites model as the dependent variable; and variables (gender, education, and work experience) as moderator have been taken in to account. (Mohammadi, 2008).

\section{Descriptive Analysis}

In this section, population demography has been stated including gender, level of education and work experience.

Distribution of respondent by Gender

\begin{tabular}{|c|c|c|c|}
\hline Gender & Male & Female & Total \\
\hline $\mathrm{N}$ & 37 & 13 & 50 \\
\hline $\mathrm{P}$ & $74 \%$ & $26 \%$ & $100 \%$ \\
\hline
\end{tabular}

Distribution of respondents according to level of education 


\begin{tabular}{|c|c|c|c|c|}
\hline $\begin{array}{c}\text { Education } \\
\text { Level }\end{array}$ & College & Becholar & $\begin{array}{c}\text { Master and } \\
\text { Higher }\end{array}$ & Total \\
\hline $\mathrm{N}$ & 10 & 28 & 12 & 50 \\
\hline $\mathrm{P}$ & $20 \%$ & $56 \%$ & $24 \%$ & $100 \%$ \\
\hline
\end{tabular}

Distribution of respondent according to work experience

\begin{tabular}{|c|c|c|c|c|}
\hline Experience & $5-12$ & $13-20$ & $21-30$ & Total \\
\hline $\mathrm{N}$ & 11 & 32 & 7 & 50 \\
\hline $\mathrm{P}$ & $22 \%$ & $64 \%$ & $14 \%$ & $100 \%$ \\
\hline
\end{tabular}

Inferential Analysis of Research Hypotheses

Analysis of the first hypothesis

\begin{tabular}{|c|c|c|c|c|}
\hline Sum & $\begin{array}{c}\text { Sense of } \\
\text { Self- } \\
\text { determination }\end{array}$ & $\begin{array}{c}\text { Sense of } \\
\text { being } \\
\text { meaningful }\end{array}$ & $\begin{array}{c}\text { Sense of } \\
\text { making } \\
\text { decisions }\end{array}$ & $\begin{array}{c}\text { Empowerment } \\
\text { Of } \\
\text { intellectual } \\
\text { capital }\end{array}$ \\
\hline 148 & 38 & 65 & 45 & $\begin{array}{c}\text { Extremely } \\
\text { High }\end{array}$ \\
\hline 234 & 85 & 76 & 73 & High \\
\hline 68 & 27 & 29 & 12 & Low \\
\hline 450 & 150 & 150 & 150 & Sum \\
\hline
\end{tabular}

\begin{tabular}{|c|c|c|c|}
\hline $\begin{array}{l}\text { Dependency } \\
\text { coefficient }\end{array}$ & $\begin{array}{l}\text { Dominant } \\
\text { options }\end{array}$ & 2 & Empowerment \\
\hline $0 / 58$ & Extremely high & $25 / 42$ & \multirow{3}{*}{$\begin{array}{c}\text { Sense of } \\
\text { making } \\
\text { decisions }\end{array}$} \\
\hline $0 / 40$ & High & $9 / 85$ & \\
\hline $0 / 45$ & High & $12 / 97$ & \\
\hline $0 / 53$ & High & $19 / 8$ & \multirow{3}{*}{$\begin{array}{r}\text { Sense of } \\
\text { being } \\
\text { meaningful }\end{array}$} \\
\hline $0 / 46$ & Low & $13 / 69$ & \\
\hline $0 / 59$ & High & $27 / 1$ & \\
\hline $0 / 48$ & High & $15 / 49$ & \multirow{3}{*}{$\begin{array}{l}\text { Sense of Self } \\
\text { determination }\end{array}$} \\
\hline $0 / 56$ & High & $22 / 79$ & \\
\hline $0 / 55$ & High & $22 / 19$ & \\
\hline
\end{tabular}

Since the critical number of 2 in the table for degrees of freedom of 2 in confidence level of $95 \%$ is equal to $5 / 99$, whenever calculated 2 is higher than 5/99, we can reject the hypothesis of homogeneity of responses and accept the dominant mode (option with the highest frequency). Comparing the results of calculated 2 with critical number of the table (5/99), since the calculated values is greater than the number 5/99, the hypothesis of Uniformity of answers is rejected and we accept that a significant relationship exists between the empowerment and organizational citizenship behavior and development of intellectual capital.

Analysis of the second hypothesis

\begin{tabular}{|c|c|c|c|c|}
\hline Sum & $\begin{array}{c}\text { Sense of } \\
\text { being } \\
\text { effective }\end{array}$ & $\begin{array}{c}\text { Sense of } \\
\text { competence }\end{array}$ & $\begin{array}{c}\text { Sense of } \\
\text { being } \\
\text { accountable }\end{array}$ & $\begin{array}{c}\text { Empowerment } \\
\text { Organization } \\
\text { citizenship } \\
\text { behaviour }\end{array}$ \\
\hline 198 & 56 & 76 & 66 & $\begin{array}{c}\text { Extremely } \\
\text { high }\end{array}$ \\
\hline
\end{tabular}


The Impact of Employee Empowerment on Intellectual Capital and Organizational Citizenship Behavior: Moderating role of Demographic

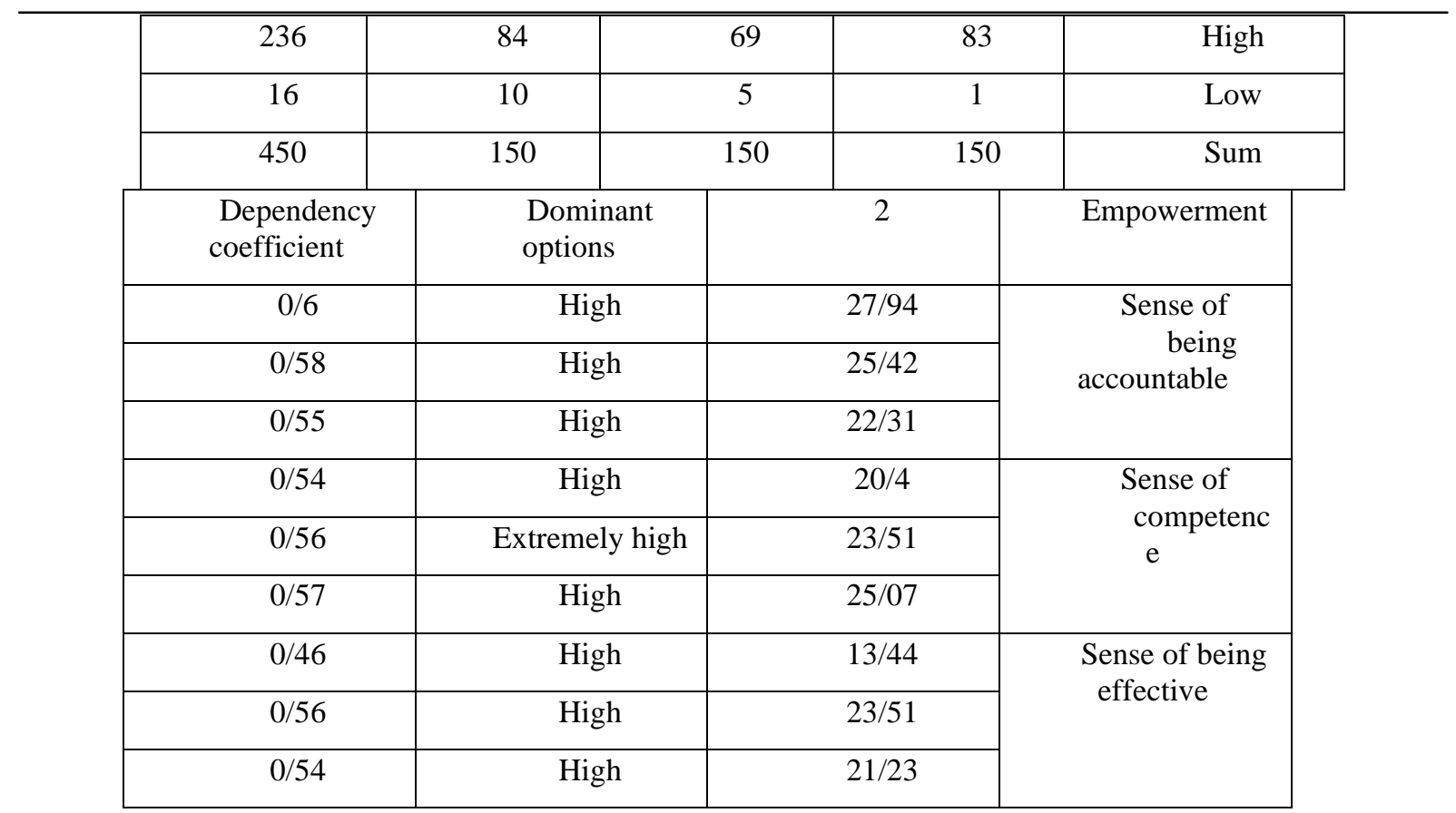

\section{Conclusions}

Human resources are critical and intangible resource for organizations giving meaning to provide backgrounds for organizational goals. Taro knows human intelligence and knowledge as the most important competitive advantage for organizations in the third millennium. He believes that if organizations want to play a role in the new challenges of the globalization process, they have to contemplate about the role of knowledge and intelligence in its organizational development and take advantage of more progressive employees (Mohseni, 2006).

The results of the current study showed that a significant positive relationship exists between employees` empowerment and organizational citizenship behavior as well as growth of intellectual capital. This means that, in fact, empowerment is an instrument that lines up personal goals with organizational ones and creates the belief that organization`s progress will lead to benefits of employees. The results of studies are clearly showed the effects of structural and psychological empowerment on business processes such as changes in attitudes and behaviors of employees. Increasing meaningful perception of task, increasing self-determination and strengthening the feeling of enjoying power to make decisions, growth in humanitarian, structural, and social dimensions of intellectual capital through the promotion of organizational values, using initiatives in carrying out tasks, improving internal processes and organizational capabilities, developing relationships and building a strong trust-and-cooperation based network can be observed. On the other hand, increased sense of accountability, competence and influencing could implement occurrence of behavior citizenship in the forms of performing a task beyond the formal definition, creating empathy and friendship among employees, active participation in solving organization`s problems and supporting the development and change, participation in extracurricular activities, increased threshold of tolerance, trying to make a healthy environment for work, timely and appropriate reactions and ultimately improving interaction between the staff and supervisors. In general, if a mechanism exists to enable the empowerment of staff, the organizational citizenship behavior will occur and intellectual capital of the organization will grow.

\section{Recommendations}

Improving and correcting replacement systems in the organization and paying attention to the principle of meritocracy. Presenting necessary trainings and skills to promote information, knowledge and job skills of employees and establishing an open flow of information within the organization. Replacing humanistic values rather than bureaucratic concepts and tools, and a new definition from human being based on the changing needs. Providing different definitions for control, evaluation, and performance management based on modification and reasoning instead of punishment and threats. Setting challenging goals for employees in accordance with the needs of the organization and a clear statement of authority and responsibilities. Redesigning jobs in the organization based on enrichment approaches, cybernetic, social information processing, and the balance between organizational dimensions - technological, human, using job analysis with the help of experts. Improving trust, honesty, and integrity environment in the organization and encouraging employees to participate in group activities and supporting the development and organizational change. Strengthening the sense of confidence in the staff through the creation of support from creativity and innovation in organizations and creating necessary fields for staff to make decisions. Redefining the management of career path of staff according to important positions of career path reflecting capacities, motivations, attitudes and perceived technical and functional competence. Elimination of unnecessary laws and regulations in the organization in order to reduce the bureaucracy and giving more authority and responsibility to staff as well as creating essential fields for independence of work for staff. 


\section{Reference}

1. Appelbaum, S., Bartolomucci, N., Beaumier, E., Boulanger, J., Corrigan, R., Dore, I, Girard, C, \& Serroni, C. (2004). Organizational citizenship behavior: a case study of culture, leadership and trust management decision, 42(1), 13-40.

2. Aghayar, S. (2003). Empowerment new method in the competitive environment.

3. Tadbir. Magazine. (135). 28.

4. Brooking, A, (1996), Intellectual Capital, International Thompson Business Press, London.

5. Gardi, B., Hamawandy, N. M., Sulaiman, V., Saeed, H., Ali, R. M., Sulaiman, A. A., \& Mahmood, S. A. (2020). The Effect of Capital Competence on the Profitability of Development and Investment Banks in Turkey. Solid State Technology, 63(5), 12571-12583.

6. Bateman, T.S., \& Organ,D.W,. (1983). Job satisfaction and the good soldier: The relationship between affect and employee citizenship. Academy of Management Journal, 26, 595.

7. Al-Kake, F., \& Hasan, N. M. (2019). The Effect of Corporate Governance on Firm's Profitability: Evidence from London Stock EX- CHANGE. International Journal of Psychosocial Rehabilitation, 23(2), 727-742. https://doi.org/10.1080/10599231.2019.1572421

8. Baban, \& Hasan, N. N. (2019). Impact of the foreign direct investment on the economy of the United Kingdom. International Journal of Psychosocial Rehabilitation, 23(2), 743-763. https://doi.org/10.37200/IJPR/V23I2/PR190328

9. Bontis, N. (1998). Intellectual Capital: An Exploratory Study that Develops Measures and Models. Managing Decision, 36(2), 63-76.

10. Chang, L.C., \& C.H. Liu. (2008). Employee Empowerment, Innovative Behavior and Job Productivity of Public Health Nurses: A cross-sectional questionnaire survey”. Int. J. Nurs. Stud., 45, 1442-1448.

11. Methane, M. (2009). Empowerment of Human Resources through Training on the Job. Beyond Management Journal, (9), 30-7.

12. (Hamawandy et al., 2020). (2020). AN EMPIRICAL INVESTIGATION HERDING BEHAVIOR IN STOCK MARKETS : A CASE STUDY. JOURNAL OF CRITICAL REVIEWS, 7(19), 7016-7020.

13. Abdullah, R., Jaff, S., Rafaat, F., Al-kake, A., \& Majeed, N. (2021). The impact of the sustainable development dimensions on the quality of financial reports. 7. https://doi.org/10.5267/j.ac.2020.11.016

14. Adl.Nawzad, H. (2020). THE IMPACT OF FOREIGN DIRECT INVESTMENT ON ECONOMIC GROWTH IN THE UNITED STATES. International Research Journal of Finance and Economics, 24(06), 1475-7192. https://doi.org/10.22610/imbr.v7i4.1166

15. Hasan, N., Omer, A. J., Othman, B., Perot, K. A., Majid, A. A., \& Kareem, F. A. (2019). Macroeconomic determinates of stock price for industrial companies listed in istanbul stock exchange. International Journal of Psychosocial Rehabilitation, 23(2), 947-963. https://doi.org/10.37200/IJPR/V23I2/PR190342

16. Jabbar, B., Al-Kake, F., Diah, M. L. M., Othman, B., \& Hasan, Z. M. (2019). This study examines the antecedents and the effects of knowledge management and information technology in the manufacturing industry. International Journal of Psychosocial Rehabilitation, 23(2), 899-908. https://doi.org/10.37200/IJPR/V23I2/PR190339

17. Karim, A. L. H. M., Al-shatnawi, H. M., Abdullah, R., Jaf, S., \& Hamawandy, N. M. (2020). The role of adopting strategic audit to improve audit quality. 7(11), 2556-2568.

18. Mahmood, M. A., Hamawandy, N. M., Sedeeq, A., Abdul, F., \& Ali, R. M. (2020). PERCEIVED EFFECT OF INTERNAL CONTROL ON THE FINANCIAL PERFORMANCE OF MANUFACTURING FIRMS IN KURDISTAN REGIONAL GOVERNMIENT OF IRAQ. 7(15), 4599_ 4614.

19. Ogiemwonyi, O., Harun, A., Othman, B., Ismael, D., Alam, M. N., \& Hamawandy, N. M. (2020). Analyzing Issues and Challenges on Environmentally Supportive Behaviour Among Malaysian and Nigerian Consumers. Sci.Int.(Lahore), ISSN 1013-5316, 32(1), 87-92. http://www.sciint.com/pdf/637182281460007063.pdf

20. Omar, R., \& Hasan, N. (2020). Activity based costing system and its role in decision making. A case study of cement companies in kurdistan region of iraq. International Journal of Psychosocial Rehabilitation, 24(6), 5915-5929. https://doi.org/10.37200/IJPR/V24I6/PR260595

21. shezad, hamawandy, raqib omer. (2020). Role of internal and external audit in public sector governance. A case study of Kurdistan regional government. International Journal of Advanced Science and Technology, 29(8 Special Issue), 1452-1462.

22. Mohseni. A. (2006). Examine and quantify the factors that affect the Empowerment of human resources (Power Distribution North West of Tehran). MSc Thesis, Tehran University, School of Management.

23. Mohammadi, F. (2008). Study of Effective Factors Influencing on the Formation of Corporate Identity and Its Effect on Organizational Citizenship Behavior and Organizational Commitment. MSc Thesis, Tehran University, School of Management. 
24. May, Douglas. R., \& Gilson, Richard. L., \& Harter, Lynn. M. (2004). The Psychological Conditions of Meaningfulness, Safety and Availability and the Engagement of the human Spirit at Work. Journal of Occupational and Organizational Psychology. The British Psychological Society, (77), 11-37.

25. Mishra, A.K. (1992). Organizational response of crisis: the role of mutual trust and top management teams. Ph.D, Disseration, university of Michigan.

26. Markoczy Livia, \& Xin Katherine. (2004). The virtues of Omission in Organizational Citizenship Behavior, University of California.

27. Seyed Javadin, R. (2013). Theory of the organization. Neghah Danesh, Publications. Stewart T. Intellectual Capital: The New Wealth of Organization. Currency Doubleday 1997, New York.

28. Seyed Javadin, R, \& Jalilian, H. (2014). Theory of advanced Management. Neghah Danesh, Publications.

29. Spreitzer, G. M. (2007). "Taking stock: Are view of more than twenty years of research on empowerment at work". The Hand Book of Organizational Behavior, Sage Publication.

30. Thomas. K, \& Velthouse. B, (1990). Cognitive Elements of Empowerment: An Interpretive Model of Intrinsic Task Iotivation. Academy of Management Review, (15), 666-681. 